\title{
The duck cytochrome oxidase I (COI) gene: Sequence and patterns analysis for potential barcoding tool
}

\author{
R. SUSANTI ${ }^{1, \boldsymbol{v}}$, RETNO SRI ISWARI ${ }^{1}$, FIDIA FIBRIANA $^{2}$, INDRIAWATI $^{3}$ \\ ${ }^{1}$ Department of Biology, Faculty of Mathematics and Natural Sciences, Universitas Negeri Semarang. Gedung D6 Lantai 1, Kampus Sekaran, \\ Gunungpati, Semarang 50229, Central Java, Indonesia. Tel./fax.: +62-24-8508112, ’email: r.susanti@mail.unnes.ac.id \\ ${ }^{2}$ Department of Integrated Science, Faculty of Mathematics and Natural Sciences, Universitas Negeri Semarang. Gedung D5 Lantai 1, Kampus Sekaran, \\ Gunungpati, Semarang 50229, Central Java, Indonesia \\ ${ }^{3}$ Research Center for Biotechnology, Indonesian Institute of Sciences. Jl. Raya Bogor Km 46, Cibinong, Bogor 16911, West Java, Indonesia
}

Manuscript received: 8 April 2018. Revision accepted: 9 May 2018.

\begin{abstract}
Susanti R, Iswari RS, Fibriana F, Indriawati. 2018. The duck cytochrome oxidase I (COI) gene: Sequence and patterns analysis for potential barcoding tool. Biodiversitas 19: 997-1003. The local duck DNA barcoding is still rarely conducted in Indonesia while DNA barcoding is extensively used as a tool of species identification and delineation tool. This study aimed to analyze the sequence and patterns of Central Javanese ducks mitochondrial cytochrome c oxidase subunit 1 (COI) gene. Feather samples of seven breeds of native duck were collected from traditional husbandries in Central Java. The samples were employed for DNA extraction and COI gene amplification. Five haplotypes were obtained from 35 samples, i.e., haplotype A, B, C, D, and E. Also, 9 variable sites with synonym substitution was detected in four nucleotides number 55, 61, 100, and 109; whereas five synonym substitutions were identified in the nucleotides number $36,48,51,66$, and 756. In conclusion, this study annotates that COI mtDNA gene is essential for local ducks barcoding system.
\end{abstract}

Keywords: Central Javanese duck; COI gene; DNA barcode; native duck

\section{INTRODUCTION}

Cytochrome c oxidase is considered as the terminal enzyme in the respiratory electron transport chain of mitochondria. The enzyme works in the inner mitochondrial membrane. Cytochrome c oxidase subunit I (CO1, COI, CCOI, COX1 or MT-CO1) is one of three mitochondrial DNA (mtDNA) encoded subunits of respiratory complex IV. The complex IV is the third and final enzyme of the electron transport chain of mitochondrial oxidative phosphorylation. It catalyzes the reduction of oxygen to water to generate the electrochemical proton gradient across the membrane that powers the production of ATP. The enzyme takes up four electrons from the positively charged $\mathrm{P}$ side (outside) of the membrane and four protons from the negatively charged $\mathrm{N}$ side (inside) for the reduction of dioxygen to two water molecules (Brändén et al. 2006).

The mitochondrial genome of animals is a better target for analysis than the nuclear genome because of its lack of introns, its limited exposure to recombination and its haploid mode of inheritance (Saccone et al. 1999). Robust primers also enable the routine recovery of specific segments of the mitochondrial genome (Simmons and Weller 2001). Past phylogenetic work has often focused on mitochondrial genes encoding ribosomal, i.e., $12 \mathrm{~S}$ and $16 \mathrm{~S}$ DNA. However, the use of the ribosomal DNA in broad taxonomic analyses is quite difficult since there are insertions and deletions (indels) which turn the sequence alignments to be more complicated (Doyle and Gaut 2000). In the animal mitochondrial genome, the 13 protein-coding genes are considered as better targets since its indels are rare, and most of the indels lead to a shift in the reading frame (Zhang and Hewitt 1997). Usually, coding genes of the mitochondrial DNA (mtDNA) are used for phylogenetic studies to distinguish species (Moore, 1997), whereas the COI (Cytochrome c oxidase subunit I) gene is considered more suitable for interspecific population studies (Hebert et al. 2003; Kerr et al. 2009). In fact, the cytochrome $c$ oxidase I gene (COI) has two significant advantages for gene-based analysis. First, COI gene has the robust universal primers which enable for recovery of its 59 ends from representatives of most animal phyla (Zhang and Hewitt, 1997). Also, COI appears to pose a greater range of phylogenetic signal than any other mitochondrial gene. Based on Knowlton and Weigt (1998), the thirdposition nucleotides of COI show a high incidence of base substitutions in common with other protein-coding genes. It leads to a rapid rate of molecular evolution that is about three times greater than that of $12 \mathrm{~S}$ or $16 \mathrm{~S}$ rDNA. This gene has a rapid evolution rate to allow the discrimination of not only closely associated species but also phylogeographic groups within a single species (Cox and Hebert, 2001; Wares and Cunningham, 2001).

MT-COI is a gene that is often used as a DNA barcode to identify animal species because its mutation rate is often fast enough to distinguish closely related species. It is also because of its sequence which is conserved among conspecifics. Contrary to the primary objection raised by skeptics that MT-COI sequence differences are too small to be detected between closely related species, more than $2 \%$ sequence divergence is typically detected between such 
organisms (Hebert et al. 2003), suggesting that the barcode are effective. DNA barcoding serves as a new tool for the taxonomist in supplementing their knowledge and also for non-experts who want to make the quick identification.

In Indonesia, duck is one of poultry commodity which less important in comparison with chicken. Duck only represent $2.24 \%$ of the total poultry population. However, duck still become one of important poultry commodity both in small-medium scale poultry and commercial poultry because of the high advantages of commercial business and high nutrition for the human. As well as providing income and feed to farmers, duck also helps as the natural predator of insects and weeds in the rice-fields. Duck population in Indonesia had been fluctuated, from 44.357.000 heads in 2012, decreased to 43.710 .000 heads in 2013. In 2014, the population increased to 45.268 .000 heads, 45.322 .000 heads in 2015, and then significantly increased to 47.360.000 heads in 2016 (Ministry of Agriculture Republic of Indonesia 2016). Epidemiologically, the domestic duck is believed to contribute as the reservoir of HPAI H5N1 viruses in eastern Asia (Hulse-Post et al. 2005; Sims et al. 2005) and to be sources of outbreaks in susceptible poultry (Gilbert et al. 2006; Sturm-Ramirez et al. 2005). The uniqueness of duck role in the ecosystem needs the effort of germplasm conservation by genetic characterization. The local duck species information is essential, especially the information on the genetic characteristics to prevent the species extinction. Genetic diversity is not only a direct benefit to livestock, but the success of livestock breeding can also be employed as a model for other species (Sponenberg 2000). COI is proving highly effective in identifying birds, butterflies, fish, flies and many other animal groups. However, there are only a few data of COI of Indonesian duck for barcoding purpose. Therefore, this study explores the mitochondrial nucleotide DNA gene encoded COI of Central Javanese duck including the analysis of its sequence and patterns for potential barcoding system.

\section{MATERIALS AND METHODS}

\section{Duck samples}

Seven breeds of Central Javanese duck, Indonesia, namely Magelang duck (SSU-M), Pekin duck (SSU-PK), Pengging duck (SSU-PG), Tegal Branjangan duck (SSUTBr), Tegal Jarakan duck (SSU-TJ, Tegal Blorong duck (SSU-TB), and Tegal Lemahan duck (SSU-TL) were used in this study. Five samples of each breed were collected for its feathers with the follicle. The feather samples were collected from the right and left wings. Total samples of this research were 35 heads.

\section{DNA extraction}

The feather samples used for DNA extraction was only the part of calamus and the rachis including its proximal umbilicus which is filled with marrow. The quality and concentration of extracted DNA were determined by $0.8 \%$ agarose gel electrophoresis and a spectrophotometer using the NanoDrop 2000C (Thermo Scientific, Waltham, MA,
USA). The extraction kit employed for DNA isolation was gSYNC ${ }^{\text {TM }}$ DNA (Geneaid Biotech Ltd., Taiwan).

\section{COI gene amplification}

COI gene amplification was performed using KAPA 2G HotStart Ready Mix Kit (Sigma-Aldrich, USA) with the composition of the $12.5 \mathrm{ul}$ ready mix; $1.5 \mathrm{ul}$ of forward primer; $1.5 \mathrm{ul}$ of reverse primer, $7.5 \mathrm{ul}$ of $\mathrm{ddH}^{2} \mathrm{O}$, and 2.0 ul of DNA samples. Forward and reverse primers were obtained from Alpha DNA (Alpha DNA, Canada). Primers used refers to Hebert et al. (2003) using forward primer BirdF1 (5'-TTCTCCAACCACAAAGACATTGGCAC-3 'and reverse primer BirdR1 5'ACGTGGGAGATAATTCCAAATCCTG-3'. PCR program was set for (1) pre-denaturation at $94{ }^{\circ} \mathrm{C}$ for 1 minutes; (2) five cycles of denaturation at $94{ }^{\circ} \mathrm{C}$ for $1 \mathrm{~min}$, annealing at $45{ }^{\circ} \mathrm{C}$ for $1.5 \mathrm{~min}$, and extension at $72{ }^{\circ} \mathrm{C}$ for $1.5 \mathrm{~min}$; (3) 30 cycles of denaturation at $94^{\circ} \mathrm{C}$ for $1 \mathrm{~min}$, annealing at $51{ }^{\circ} \mathrm{C}$ for $1.5 \mathrm{~min}$, and extension at $72{ }^{\circ} \mathrm{C}$ for $1.5 \mathrm{~min}$; and (4) final extension at $72{ }^{\circ} \mathrm{C}$ for 5 minutes. Next, the PCR results were visualized using 1.2\% agarose gel. Agarose powder used was A9539 SIGMA Agarose BioReagent (Sigma-Aldrich, USA). The expected PCR product was $746 \mathrm{bp}$. The PCR products were purified using QIAquick PCR Purification Kit (Qiagen, Germany) to ensure the absence of contamination. The results were then sequenced using dideoxy termination method with $\mathrm{ABI}$ automatic sequencer (Applied Biosystems, USA) by $1^{\text {st }}$ BASE Pte. Ltd. (Singapore) via PT. Genetika Science Indonesia.

\section{Statistical analysis}

The sequences were aligned using ClustalW of Molecular Evolutionary Genetics Analysis (MEGA) software version 6.06. The nucleotide sequence of COI gene was analyzed using Basic Local Alignment Search Tool (BLAST) NCBI to determine their homology with the GenBank data. Identical sequences were considered as the same haplotype. All haplotype species of COI gene of Central Javanese duck included in Genbank data. Nucleotide sequences of COI gene of mtDNA from Central Javanese duck in this research together with other Anas isolates from Genbank were aligned with ClustalW of MEGA-6.06 program (Tamura et al. 2013). Estimation of genetic distance and phylogenetic tree construction were analyzed with Neighbor-Joining method and calculation of distance matrix with Kimura 2-parameter model, and the bootstrap value was 1,000 . At the same time, the complete sequences of Anas platyrhynchos and another Anas species from GenBank were selected as controls.

\section{RESULTS AND DISCUSSION}

\section{COI gene amplification}

PCR results of COI gene of local ducks are shown in Figure 1. Based on this visualization, the COI gene of Central Javanese duck was successfully amplified by using BirdF1-BirdR1 primers. All samples show 746 bp PCR product with clear and bold DNA band which indicates the 
optimal PCR conditions were achieved and the process was conducted properly. Then, the $746 \mathrm{bp}$ fragment of the COI region was sequenced.

\section{COI gene sequence analysis}

Online BLAST analysis indicated that all duck sample in this research had a $99-100 \%$ homology with duck COI gene of Anas platyrhynchos (GenBank Accession Number KJ778676.1 and KJ833586.1). The Basic Local Alignment Search Tool (BLAST) finds regions of local similarity between protein or nucleotide sequences. Moreover, the program compares nucleotide or protein sequences to the sequence in a database and calculates the statistical significance of the matches (Wheeler and Bhagwat 2007). COI sequence on the database (Access Code KJ778676.1 and KJ833586.1) different $1 \%$ with COI sequence sample in this research due to mutation.

Multiple alignments obtained were 733 nucleotides at position 32 to 764 at the 5 'end. A total number of 9 variable sites were identified. Out of the nine polymorphic sites, all were caused by transitions or transversions. No deletion and insertion mutation. All haplotype of Central Javanese local duck has the substitution of C48T, T51C, and C758T. Based on these polymorphic sites, all samples show five haplotypes (Table 1). The sequence alignment reveals a low intraspecific variation within duck. Compared to the D-loop gene, the COI gene of Javanese duck show only a few polymorphic sites and haplotypes formed. The analysis of 718 nucleotides from D-loop genes in 35 samples of Central Javanese duck showed 32 polymorphic sites and 23 haplotypes (Susanti et al. 2017). Based on Table 1, it can be seen that the types of ducks that show variations are 2 Tegal Branjangan ducks (haplotype B and E) and 2 Pekin duck (haplotype C and D).
Nucleotide sequences of COI duck genes coexisted with Anas platyrhynchos (GenBank Acc Number KJ778676.1), 243 codons from 12-254 were identified. Also, the varied number of synonym codons and non-synonym substitutions were identified for each haplotype as shown Table 2. Five synonym substitution (nucleotides number 36, 48, 51, 66, 756) and 4 non-synonym substitutions (nucleotides number $55,61,100,109$ ) of 9 polymorphic sites were identified. The four non-synonym substitutions show mutations in the amino acids; L19V, L34I, L21I, and L37V; whereas all non-synonym substitutions were present in 4 haplotypes (B, C, D, and E) each consisting of 1 duck. While 31 other duck samples represent haplotype A, only experienced four non-synonym substitutions only.

Reconstruction of phylogenetic trees of Central Javanese ducks with another Anas forms two clusters as presented Figure 2. In this study, phylogenetic analysis based on partial COI sequences (total consensus sequences is $733 \mathrm{bp}$ ) show that all Central Javanese duck haplotypes were found in the same cluster with already reported Anas platyrhynchos and Anas poecilorhyncha (Figure 2). Like the phylogenetic tree constructed for COI, the Central Javanese ducks and other Anas platyrhynchos species are not separated in the different cluster. $\square$

Genetic distance in this study was analyzed using the Pairwise Distance Calculation (Tamura et al. 2013). Nucleotides of Central Javanese duck COI mtDNA were aligned with the other Anas spp species in the world, i.e., Anas platyrhynchos (KJ778676.1; KJ833586.1, and KJ883269.1), Anas poecilorhyncha (JN703241.1; JN703235.1), Anas acuta (DQ432717.1; JN703181.1), and Cairina moschata (DQ432792.1; JX166610.1) as out of the group. Genetic distances ranging from 0:00 to 0.131 (Table $3)$.

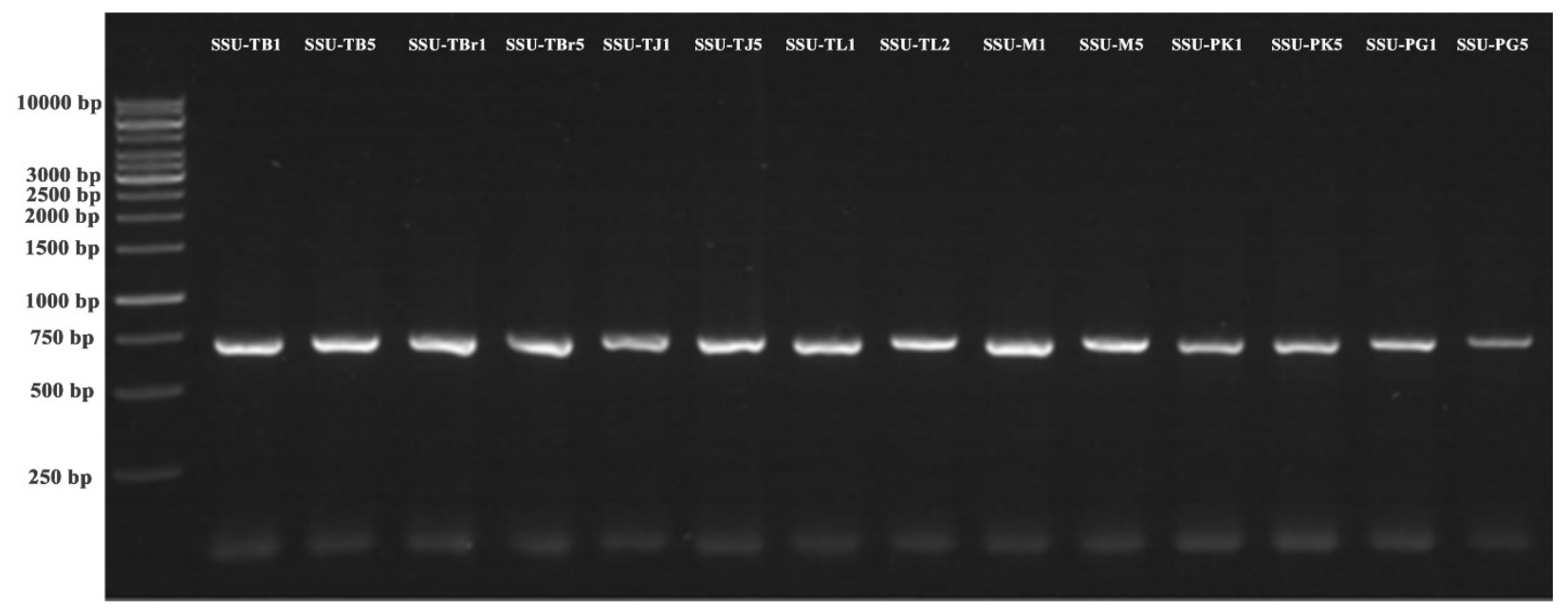

Figure 1. PCR amplicon of COI gene on all types of central Javanese ducks DNA samples shows 746 bp in length product in $1.2 \%$ agarose gel with $1 \mathrm{~Kb}$ DNA ladder 
Table 1. The identified haplotype of the mitochondrial COI sequence polymorphism in seven types of Central Javanese duck.

\begin{tabular}{|c|c|c|c|c|c|c|c|c|c|c|}
\hline \multirow{2}{*}{ Type of Central Javanese Duck } & \multirow{2}{*}{ Haplotype } & \multicolumn{9}{|c|}{ Nucleotide polymorphism } \\
\hline & & 36 & 48 & 51 & 55 & 61 & 66 & 100 & 109 & 756 \\
\hline KJ778676.1 & KJ778676.1 & $\mathrm{T}$ & $\mathrm{C}$ & $\mathrm{T}$ & $\mathrm{C}$ & $\mathrm{C}$ & $\mathrm{C}$ & $\mathrm{C}$ & $\mathrm{C}$ & $\mathrm{C}$ \\
\hline Tegal Blorong duck -1 (SSU-TB1) & A & $\mathrm{C}$ & $\mathrm{T}$ & $\mathrm{C}$ & & & & & & $\mathrm{T}$ \\
\hline Tegal Blorong duck -2 (SSU-TB2) & A & $\mathrm{C}$ & $\mathrm{T}$ & $\mathrm{C}$ & & & & & & $\mathrm{T}$ \\
\hline Tegal Blorong duck -3 (SSU-TB3) & A & $\mathrm{C}$ & $\mathrm{T}$ & $\mathrm{C}$ & & & & & & $\mathrm{T}$ \\
\hline Tegal Blorong duck -4 (SSU-TB4) & $\mathrm{A}$ & $\mathrm{C}$ & $\mathrm{T}$ & $\mathrm{C}$ & & & & & & $\mathrm{T}$ \\
\hline Tegal Blorong duck-5 (SSU-TB5) & A & $\mathrm{C}$ & $\mathrm{T}$ & $\mathrm{C}$ & & & & & & $\mathrm{T}$ \\
\hline Tegal Branjangan duck-1 (SSU-TBr1) & A & $\mathrm{C}$ & $\mathrm{T}$ & $\mathrm{C}$ & & & & & & $\mathrm{T}$ \\
\hline Tegal Branjangan duck-2 (SSU-TBr2) & B & $\mathrm{C}$ & $\mathrm{T}$ & $\mathrm{C}$ & G & & & & & $\mathrm{T}$ \\
\hline Tegal Branjangan duck-3 (SSU-TBr3) & $\mathrm{E}$ & $\mathrm{C}$ & $\mathrm{T}$ & $\mathrm{C}$ & G & G & & & G & $\mathrm{T}$ \\
\hline Tegal Branjangan duck-4 (SSU-TBr4) & A & $\mathrm{C}$ & $\mathrm{T}$ & $\mathrm{C}$ & & & & & & $\mathrm{T}$ \\
\hline Tegal Branjangan duck-5 (SSU-TBr5) & A & $\mathrm{C}$ & $\mathrm{T}$ & $\mathrm{C}$ & & & & & & $\mathrm{T}$ \\
\hline Tegal Jarakan duck-1 (SSU-TJ1) & A & $\mathrm{C}$ & $\mathrm{T}$ & $\mathrm{C}$ & & & & & & $\mathrm{T}$ \\
\hline Tegal Jarakan duck-2 (SSU-TJ2) & A & $\mathrm{C}$ & $\mathrm{T}$ & $\mathrm{C}$ & & & & & & $\mathrm{T}$ \\
\hline Tegal Jarakan duck-3 (SSU-TJ3) & A & $\mathrm{C}$ & $\mathrm{T}$ & $\mathrm{C}$ & & & & & & $\mathrm{T}$ \\
\hline Tegal Jarakan duck-4 (SSU-TJ4) & A & $\mathrm{C}$ & $\mathrm{T}$ & $\mathrm{C}$ & & & & & & $\mathrm{T}$ \\
\hline Tegal Jarakan duck-5 (SSU-TJ5) & A & $\mathrm{C}$ & $\mathrm{T}$ & $\mathrm{C}$ & & & & & & $\mathrm{T}$ \\
\hline Tegal lemahan duck-1 (SSU-TL1) & A & $\mathrm{C}$ & $\mathrm{T}$ & $\mathrm{C}$ & & & & & & $\mathrm{T}$ \\
\hline Tegal lemahan duck-2 (SSU-TL2) & A & $\mathrm{C}$ & $\mathrm{T}$ & $\mathrm{C}$ & & & & & & $\mathrm{T}$ \\
\hline Tegal lemahan duck-3 (SSU-TL3) & A & $\mathrm{C}$ & $\mathrm{T}$ & $\mathrm{C}$ & & & & & & $\mathrm{T}$ \\
\hline Tegal lemahan duck-4 (SSU-TL4) & A & $\mathrm{C}$ & $\mathrm{T}$ & $\mathrm{C}$ & & & & & & $\mathrm{T}$ \\
\hline Tegal lemahan duck-5 (SSU-TL5) & A & $\mathrm{C}$ & $\mathrm{T}$ & $\mathrm{C}$ & & & & & & $\mathrm{T}$ \\
\hline Magelang duck-1 (SSU-M1) & A & $\mathrm{C}$ & $\mathrm{T}$ & $\mathrm{C}$ & & & & & & $\mathrm{T}$ \\
\hline Magelang duck-2 (SSU-M2) & A & $\mathrm{C}$ & $\mathrm{T}$ & $\mathrm{C}$ & & & & & & $\mathrm{T}$ \\
\hline Magelang duck-3 (SSU-M3) & A & $\mathrm{C}$ & $\mathrm{T}$ & $\mathrm{C}$ & & & & & & $\mathrm{T}$ \\
\hline Magelang duck-4 (SSU-M4) & A & $\mathrm{C}$ & $\mathrm{T}$ & $\mathrm{C}$ & & & & & & $\mathrm{T}$ \\
\hline Magelang duck-5 (SSU-M5) & A & $\mathrm{C}$ & $\mathrm{T}$ & $\mathrm{C}$ & & & & & & $\mathrm{T}$ \\
\hline Pekin duck-1 (SSU-PK1) & $\mathrm{C}$ & G & $\mathrm{T}$ & $\mathrm{C}$ & G & & $\mathrm{T}$ & & & $\mathrm{T}$ \\
\hline Pekin duck-2 (SSU-PK2) & $\mathrm{D}$ & $\mathrm{C}$ & $\mathrm{T}$ & $\mathrm{C}$ & & & & A & & $\mathrm{T}$ \\
\hline Pekin duck-3 (SSU-PK3) & A & $\mathrm{C}$ & $\mathrm{T}$ & $\mathrm{C}$ & & & & & & $\mathrm{T}$ \\
\hline Pekin duck-4 (SSU-PK4) & A & $\mathrm{C}$ & $\mathrm{T}$ & $\mathrm{C}$ & & & & & & $\mathrm{T}$ \\
\hline Pekin duck-5 (SSU-PK5) & A & $\mathrm{C}$ & $\mathrm{T}$ & $\mathrm{C}$ & & & & & & $\mathrm{T}$ \\
\hline Pengging duck-1 (SSU-PG1) & A & $\mathrm{C}$ & $\mathrm{T}$ & $\mathrm{C}$ & & & & & & $\mathrm{T}$ \\
\hline Pengging duck-2 (SSU-PG2) & A & $\mathrm{C}$ & $\mathrm{T}$ & $\mathrm{C}$ & & & & & & $\mathrm{T}$ \\
\hline Pengging duck-3 (SSU-PG3) & A & $\mathrm{C}$ & $\mathrm{T}$ & $\mathrm{C}$ & & & & & & $\mathrm{T}$ \\
\hline Pengging duck-4 (SSU-PG4) & A & $\mathrm{C}$ & $\mathrm{T}$ & $\mathrm{C}$ & & & & & & $\mathrm{T}$ \\
\hline Pengging duck-5 (SSU-PG5) & A & $\mathrm{C}$ & $\mathrm{T}$ & $\mathrm{C}$ & & & & & & $\mathrm{T}$ \\
\hline
\end{tabular}

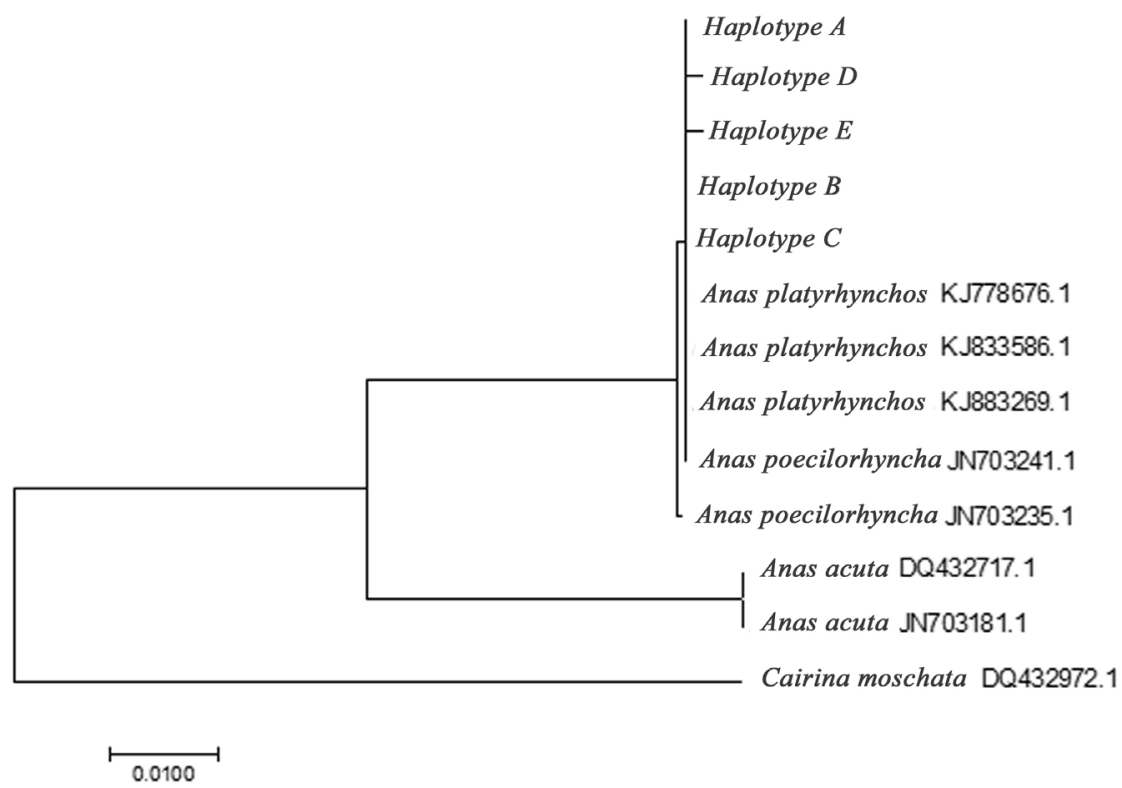

Figure 2. Neighbor-joining (NJ) tree with 1000 bootstrap replication for Central Javanese duck and other Anas spp breeds from GenBank based COI gene 
Table 2. Synonym and non-synonym substitution in mitochondrial COI gene of central Javanese duck in this study

\begin{tabular}{lccccc}
\hline Haplotype & $\begin{array}{c}\text { Number of } \\
\text { codons }\end{array}$ & $\begin{array}{c}\text { Number } \\
\text { substitution }\end{array}$ & $\begin{array}{c}\text { Number of synonym } \\
\text { substitution }\end{array}$ & $\begin{array}{c}\text { Number of non- } \\
\text { synonym substitution }\end{array}$ & $\begin{array}{c}\text { Amino acids } \\
\text { substitution }\end{array}$ \\
\hline Haplotype A & 243 & 4 & 4 & 0 & 0 \\
Haplotype B & 243 & 5 & 4 & 1 & L19V \\
Haplotype C & 243 & 6 & 5 & 1 & L19V \\
Haplotype D & 243 & 5 & 4 & 1 & L34I \\
Haplotype E & 243 & 7 & 4 & 3 & L19V, L21I, L37V \\
\hline
\end{tabular}

Table 3. Results of pairwise distance calculation

\begin{tabular}{|c|c|c|c|c|c|c|c|c|c|c|c|c|c|}
\hline & 1 & 2 & 3 & 4 & 5 & 6 & 7 & 8 & 9 & $\mathbf{0}$ & 11 & 12 & 13 \\
\hline Haplotype A & 0.000 & & & & & & & & & & & & \\
\hline 2. Haplotype B & 0.000 & 0.000 & & & & & & & & & & & \\
\hline Haplotype C & 0.000 & 0.000 & 0.000 & & & & & & & & & & \\
\hline 4. Haplotype D & 0.002 & 0.002 & 0.002 & 0.000 & & & & & & & & & \\
\hline 5. Haplotype E & 0.002 & 0.002 & 0.002 & 0.003 & 0.000 & & & & & & & & \\
\hline 6. Anas platyrhynchos KJ778676.1 & 0.000 & 0.000 & 0.000 & 0.002 & 0.002 & 0.000 & & & & & & & \\
\hline 7. Anas platyrhynchos KJ833586.1 & 0.000 & 0.000 & 0.000 & 0.002 & 0.002 & 0.000 & 0.000 & & & & & & \\
\hline 8. Anas platyrhynchos KJ883269.1 & 0.000 & 0.000 & 0.000 & 0.002 & 0.002 & 0.000 & 0.000 & 0.000 & & & & & \\
\hline 9. Anas poecilorhyncha JN703235.1 & 0.002 & 0.002 & 0.002 & 0.003 & 0.003 & 0.002 & 0.002 & 0.002 & 0.000 & & & & \\
\hline 10. Anas poecilorhyncha JN703241.1 & 0.000 & 0.000 & 0.000 & 0.002 & 0.002 & 0.000 & 0.000 & 0.000 & 0.002 & 0.000 & & & \\
\hline 11. Anas acuta DQ432717.1 & 0.064 & 0.064 & 0.064 & 0.066 & 0.066 & 0.064 & 0.064 & 0.064 & 0.065 & 0.064 & 0.000 & & \\
\hline 12. Anas acuta JN703181.1 & 0.064 & 0.064 & 0.064 & 0.066 & 0.066 & 0.064 & 0.064 & 0.064 & 0.065 & 0.064 & 0.000 & 0.000 & \\
\hline 13. Cairina moschata DQ432972.1 & 0.129 & 0.129 & 0.129 & 0.131 & 0.131 & 0.129 & 0.129 & 0.129 & 0.127 & 0.129 & 0.134 & 0.134 & 0.000 \\
\hline
\end{tabular}

\section{Discussion}

Cytochrome c oxidase enzyme is a small, highly conserved, and heme-containing bifunctional protein. It has been studied extensively, not only for its role in electron transport, but also for its role in apoptosis, it releases from the mitochondria in response to specific apoptotic stimuli (Wang, 2001). Cytochrome c oxidase is an oligomeric enzymatic complex located in the inner membrane of mitochondria. Cytochrome c oxidase consists of three large primarily catalytic subunits encoded by the mtDNA and 10 smaller subunits encoded by nuclear genes. The nuclearencoded subunits are thought to modulate enzyme function. In vertebrates, cytochrome c oxidase is composed of 13subunits, and a further 30 proteins are required for proper cytochrome c oxidase assembly (Boopathi et al. 2004). In eukaryotes, this enzyme complex is located in the inner membrane of mitochondria. It is considered to be a major site of mitochondrial oxidative phosphorylation regulation. This rate-limiting enzyme is also implicated in the production of reactive oxygen species (ROS) under oxidative stress conditions (Lee et al. 2001; Lee et al. 2002; Vijayasarathy et al. 2003).

GenBank aims for comprehensive coverage of genomic diversity of both micro and macro-organism, and the GBS database aims for taxonomic coverage of just a single gene like COI. Principally, the COI database could serve as the basic reference for a global bioidentification system (GBS) for animals. Through web-based delivery, this system could provide easy access to taxonomic information, a particular benefit to developing nations. Once established, this microgenomic identification system will overcome the deficits of morphological approaches to species discrimination: the bounds of intraspecific diversity will be quantifiable, sibling species will be recognizable, taxonomic decisions will be objective, and all life stages will be identifiable.

Conceptually, any consistent, nonzero sequence variation that distinguishes two species should work as a DNA barcode. Furthermore, DNA barcodes do not require any demonstration of the homology of mutations as would be needed in a phylogenetic marker. In other words, low levels of divergence may be sufficient to distinguish among species even if not adequate to estimate phylogenetic relationships. Relative to $\mathrm{CO} 1$ in animals, the mean divergence level between species in plants is usually quite low (Kress and Erickson 2007; Shaw et al. 2007).

In resolving such cases of late divergence, it is probable that COI might be matched by other mitochondrial genes since this gene tends to provide deeper phylogenetic insights than alternatives such as cytochrome $b$ (Simmons and Weller 2001). This is due to its slower amino-acid sequence occurrence any other than mitochondrial gene (Lynch \& Jarrell, 1993). As a result, by examining aminoacid substitutions, it may be possible to assign any unidentified organism to a higher taxonomic group (e.g., phylum, order), before examining nucleotide substitutions to determine its species identity.

Based on the COI sequences and the NJ tree, this study noted Anas species with identical haplotypes such as $A$. platyrhynchos and $A$. poecilorhyncha. In fact, the hybridization plays a significant role in confounding phylogenetic relationships (Lavretsky et al. 2014). 
However, there is a lack of documentation for fertile hybrids formed between $A$. platyrhynchos and $A$. poecilorhyncha individuals, $A$. platyrhynchos is known to hybridize with the Chinese Spot-billed Duck $A$. zonorhyncha, the Indian Spot-billed Duck's eastern counterpart (Kulikova et al. 2005). Upon Random Amplified Polymorphic DNA analysis, a study by Kulikova et al. (2003) reported low genetic differentiation between $A$. platyrhynchos and A. poecilorhyncha.

In Indonesia, the people have a high demand for the duck egg. The common local duck species have 100-125 eggs production per year. Ducks for meat production are commonly obtained from Pekin duck (Anas domesticus), Muscovy duck (Cairina moschata) and the hybrid of Muscovy duck with common duck (Anas platyrhynchos) so-called as Blengong or Tiktok and internationally known as Mule Duck. When Muscovies and common ducks are allowed to mate naturally, the fertility rate is usually meager, the offspring are sterile and cannot be used for breeding. Therefore, sometimes, those ducks are employed for dual purposes as the meat producer and egg producer. Also, to fulfill the demand, the dual purpose is also applied in Pekin ducks from Australia and the hybridization of Indian Runner ducks (laying) with the white Khaki Campbell duck (Sexton 2013; Ipek and Sozcu 2017). Then, the traditional duck farmers maintain and domesticate the Pekin duck in their husbandry. Sometimes they mix the local duck with Pekin duck and the hybridization between this species is unavoidable. The farmer like to maintain this kind of husbandry method since they think that by hybridization, the viable offspring will be better than the original one. Steczny et al. (2017) study showed that Pekin duck average bodyweights both for males and females weight increased with age up to 49 days old. Moreover, the daily weight gains were higher in males than in females with the highest value was noted between 22 and 35 days old, and the lowest until 21 days of growth.

Tegal duck is a species of ducks with rapid egg production. Tegal duck is a local name for the duck in one city/district area in Central Java but is very commonly used by all farmers in Java Island. This duck can go through long distances when herding from one area to other areas, has a vertical body shape like a bottle with height 45-50 $\mathrm{cm}$. Common color of Tegal duck is browny, or many brown spots or so-called as branjangan with some variation of color as reddish with the black color of beak and feet (Hidayati et al. 2016).

In this study, local duck Anas platyrhynchos with 7 different breeds were employed as the sample which based on the morphological characteristics, the fur color and level of production are different. Based on the polymorphism analysis on COI mtDNA sequences produced 5 haplotypes; whereas the nucleotide sequence analysis of COI mtDNA identified 9 variable sites. The haplotypes indicate the low diversity of these ducks based on the COI gene where COI serves as the identity/barcode of duck species. In comparison with the ducks D-loop genes, the diversity of duck species shows 23 haplotypes (Susanti et al. 2017). COI can serve as a barcode if the variation is very small within species. The variations in all ducks in this study were based on the nucleotide variation of the COI gene. In fact, the different nucleotides are only at 9 sites; all were caused by substitution and no deletion or insertion mutation. Of the 9 substitutions, only 4 are nonsynonymous substitutions (nucleotide substitution followed by amino acid substitution). Non-synonym substitution was detected in four sequences $(55,61,100$, and 109 nucleotide number); whereas synonym substitution was identified in five sequences nucleotides number 36, 48, 51, 66, and 756 . The change of 4 amino acids is not necessarily followed by changes in the structure and function of COI protein. COI enzymes are enzymes involved in the oxidative phosphorylation process. Thus, amino acid changes in the COI gene have no implications for the duck phenotype. This feather color difference, not due to the variation of the nucleotide of COI gene.

The results indicate that COI gene is likely to be utilized as a barcoding system on local duck (Anas platyrhynchos). Furthermore, a gene region could be classified as a DNA barcode after accomplishing three criteria: (i) include significant genetic variability and divergence of species-level, (ii) in terms of wide taxonomic application, the development of universal PCR primers should have conserved flanking sites, and (iii) possess an adequate length of sequence in order to facilitate present skills of DNA extraction and amplification. The COI gene information of Central Javanese ducks has great importance for the barcoding system, and also for quick identification. Moreover, it is useful for the conservation, utilization, and future breed conservation strategy of local ducks. This study remarks that COI mtDNA gene is important for local ducks barcoding system.

\section{ACKNOWLEDGEMENTS}

The author would like to thank the Directorate of Research and Community Service, Indonesia Ministry of research, Technology and higher education which fully supports this research through Fundamental Research Fund 2015-2016.

\section{REFERENCES}

Boopathi E, Lenka N, Prabu SK, Fang JK, Wilkinson F, Atchison M, Avadhani NG. 2004. Regulation of murine cytochrome c oxidase vb gene expression during myogenesis yy-1 and heterogeneous nuclear ribonucleoprotein d-like protein (jktbp1) reciprocally regulate transcription activity by physical interaction with the berf-1/zbp- 89 factor. J Biol Chem 279 (34): 35242-35254.

Brändén G, Gennis RB, Brzezinski P. 2006. Transmembrane proton translocation by cytochrome c oxidase. Biochimica Biophys Acta (BBA)-Bioenerg 1757 (8): 1052-1063.

Cox AJ, Hebert PD. 2001. Colonization, extinction, and phylogeographic patterning in a freshwater crustacean. Mol Ecol 10 (2): 371-386.

Doyle JJ, Gaut BS. 2000. Evolution of genes and taxa: a primer. Plant Mol Evol. Springer, Berlin.

Gilbert M, Chaitaweesub P, Parakamawongsa T, Premashthira S, Tiensin T, Kalpravidh W, Slingenbergh J. 2006. Free-grazing ducks and highly pathogenic avian influenza, Thailand. Emerg Infect Dis 12 (2): 227.

Hebert PD, Cywinska A, Ball SL. 2003. Biological identifications through DNA barcodes. Proc R Soc Lond B Biol Sci 270 (1512): 313-321. 
Hebert PD, Ratnasingham S, de Waard JR. 2003. Barcoding animal life: cytochrome c oxidase subunit 1 divergences among closely related species. Proc R Soc Lond B Biol Sci 270 (Suppl 1): S96-S99.

Hidayati NN, Yuniwarti EYW, Isdadiyanto S. 2016. Perbandingan kualitas daging itik magelang, itik pengging dan itik Tegal. Bioma: Berkala Ilmiah Biologi 18 (2): 56-63.

Hulse-Post D, Sturm-Ramirez K, Humberd J, Seiler P, Govorkova E, Krauss S, Nguyen T. 2005. Role of domestic ducks in the propagation and biological evolution of highly pathogenic $\mathrm{H} 5 \mathrm{~N} 1$ influenza viruses in Asia. Proc Natl Acad Sci USA 102 (30): 10682-10687.

Ipek A, Sozcu A. 2017. Comparison of hatching egg characteristics, embryo development, yolk absorption, hatch window, and hatchability of Pekin Duck eggs of different weights. Poult Sci 96 (10): 3593-3599

Kerr KC, Birks SM, Kalyakin MV, Red'kin YA, Koblik EA, Hebert PD. 2009. Filling the gap-COI barcode resolution in eastern Palearctic birds. Front Zool 6 (1): 29

Knowlton N, Weigt LA. 1998. New dates and new rates for divergence across the Isthmus of Panama. Proc R Soc Lond B: Biol Sci 265 (1412): 2257-2263.

Kress WJ, Erickson DL. 2007. A two-locus global DNA barcode for land plants: the coding $r b c L$ gene complements the non-coding trnH-psbA spacer region. PLoS One 2 (6): e508. DOI: 10.1371/journal.pone.0000508.

Kulikova I, Chelomina G, Zhuravlev YN. 2003. Low genetic differentiation of and close evolutionary relationships between Anas platyrhynchos and Anas poecilorhyncha: RAPD-PCR Evidence. Russ J Genet 39 (10): 1143-1151.

Kulikova IV, Drovetski SV, Gibson DD, Harrigan RJ, Rohwer S, Sorenson MD, McCracken KG. 2005. Phylogeography of the mallard (Anas platyrhynchos): Hybridization, dispersal, and lineage sorting contribute to complex geographic structure. The Auk 122 (3): 949965.

Lavretsky P, McCracken KG, Peters JL. 2014. Phylogenetics of a recen radiation in the mallards and allies (Aves: Anas): inferences from a genomic transect and the multispecies coalescent. Mol Phylogenet Evol 70: 402-411.

Lee I, Bender E, Arnold S, Kadenbach B. 2001. New control of mitochondrial membrane potential and ROS formation a hypothesis. Biol Chem 382 (12): 1629-1633.

Lee I, Bender E, Kadenbach B. 2002. Control of mitochondrial membrane potential and ROS formation by reversible phosphorylation of cytochrome c oxidase. Mol Cell Biochem 234 (1): 63-70.

Lynch M, Jarrell P. 1993. A method for calibrating molecular clocks and its application to animal mitochondrial DNA. Genetics 135 (4): 1197 1208.

Ministry of Agriculture Republic of Indonesia. 2016. Statistik Pertanian (Agricultural Statistics 2016). Center for Agricultural Data and
Information System Ministry of Agriculture, Republic of Indonesia, Jakarta

Moore WS. 1997. The window of taxonomic resolution for phylogenies based on mitochondrial cytochrome b. Avian Mol Evol Syst: 84-119.

Saccone C, De Giorgi C, Gissi C, Pesole G, Reyes A. 1999. Evolutionary genomics in Metazoa: The mitochondrial DNA as a model system. Gene 238 (1): 195-209.

Shaw J, Lickey EB, Schilling EE, Small RL. 2007. Comparison of whole chloroplast genome sequences to choose noncoding regions for phylogenetic studies in angiosperms: the tortoise and the hare III. Am J Bot, 94 (3): 275-288.

Simmons R, Weller S. 2001. Utility and evolution of cytochrome b in insects. Mol Phylogenet Evol 20 (2): 196-210.

Sims L, Domenech J, Benigno C, Kahn S, Kamata A, Lubroth J, Roeder P. 2005. Origin and evolution of highly pathogenic H5N1 avian influenza in Asia. Vet Rec 157 (6): 159.

Sponenberg DP. 2000. Genetic resources and their conservation. In: Bowling AT, Ruvinsky A (eds.). The Genetics of the Horse. CABI Publishing, Wallingford, UK.

Steczny, K., Kokoszynski, D., Bernacki, Z., Wasilewski, R., \& Saleh, M. 2017. Growth performance, body measurements, carcass composition and some internal organ characteristics in young Pekin ducks. S Afr J Animal Sci 47 (3): 399-406.

Sturm-Ramirez K, Hulse-Post D, Govorkova E, Humberd J, Seiler P, Puthavathana P, Long H. 2005. Are ducks contributing to the endemicity of highly pathogenic H5N1 influenza virus in Asia? J Virol 79 (17): 11269-11279.

Susanti R, Iswari RS, Fibriana F, Sari RI. 2017. Mitochondrial D-loop sequence variation among Central Javanese Duck in Indonesia. Acta Sci Animal Sci 39 (4): 449-456.

Tamura K, Stecher G, Peterson D, Filipski A, Kumar S. 2013. MEGA6: molecular evolutionary genetics analysis version 6.0. Mol Biol Evol 30 (12): 2725-2729.

Vijayasarathy C, Damle S, Prabu SK, Otto CM, Avadhani NG. 2003. Adaptive changes in the expression of nuclear and mitochondrial encoded subunits of cytochrome c oxidase and the catalytic activity during hypoxia. FEBS J 270 (5): 871-879.

Wang X. 2001. The expanding role of mitochondria in apoptosis. Genes Dev 15 (22): 2922-2933.

Wares JP, Cunningham CW. 2001. Phylogeography and historical ecology of the North Atlantic intertidal. Evolution 55 (12): 2455-2469.

Wheeler D, Bhagwat M. 2007. BLAST QuickStart. Comparative Genomics. Springer, Berlin.

Zhang DX, Hewitt G. 1997. Assessment of the universality and utility of a set of conserved mitochondrial COI primers in insects. Insect Mol Biol 6 (2): 143-150. 